\title{
Public protection in youth justice? The Intensive Supervision and Surveillance Programme from the inside
}

\author{
Tom Ellis ${ }^{\dagger}$, Nick Pamment ${ }^{\ddagger}$ and Chris Lewis ${ }^{\ddagger}$ \\ $\dagger$ (Corresponding author) Institute of Criminal Justice Studies, University of Portsmouth, \\ Ravelin House, Museum Road, P01 2QQ. Email: tom.ellis@port.ac.uk \\ ‡Institute of Criminal Justice Studies, University of Portsmouth, Ravelin House, Museum \\ Road, P01 2QQ.
}

Received 19 January 2009; revised and accepted 21 April 2009

Keywords: public protection, youth justice, intensive supervision, effectiveness, young offenders' views, staff views

Tom Ellis is a principal lecturer at the Institute of Criminal Justice Studies at the University of Portsmouth. His areas of expertise include Japanese criminal justice, youth justice, prisons, prostitution, and race, diversity and criminal justice, where he sits on the Ministry of Justice's Race Statistics Advisory Board. Until 1999, he worked for the Home Office Research, Development and Statistics Directorate and also had a two-year spell at UNICRI based in Rome.

Nick Pamment is a recent Master's graduate of ICJS and is now completing his Professional Doctorate in Criminal Justice. He has a research background in policing and youth justice and is now researching reparation orders and also youth justice in Japan and South Korea.

Chris Lewis is the former head of Corrections statistics in the Home Office and is now a visiting professor and senior research fellow at the Institute of Criminal Justice Studies at the University of Portsmouth. He also works for the World Bank looking at criminal justice statistics. His research interests in addition to youth justice are Japanese criminal justice, gun and knife crime, international and comparative criminal justice statistics; prosecution systems; police operations and diversity and criminal justice, where he sits on the Ministry of Justice's Race Statistics Advisory Board.

\section{Abstract}

In 2001, the Youth Justice Board of England \& Wales introduced the Intensive Supervision and Surveillance Programme (ISSP). It was quickly hailed as the most robust community-based sanction available for the most serious and persistent young offenders. However, it has been dogged by high reconviction rates. This paper undertakes first a review of the international evidence base for the effectiveness of all types of intensive supervision, before focusing specifically on its effectiveness within youth justice. It then presents our findings from fieldwork (participant observation, interviews and questionnaires) carried out within two Youth Offending Teams, comparing the views of supervisors and the supervised young offenders. The conclusions show that ISSP is not founded on sound evidence. Our own evidence suggests a number of reasons why ISSP does not work, and is not likely to, in its present form. Most importantly, it is clear that ISSP cannot provide the level of public protection claimed with such a severe offending group, and therefore does not aid the realistic promotion of greater use of community sentences. The article makes suggestions for an alternative approach to dealing with serious and persistent offenders in the community, based on the views of the young offenders subject to ISSP and the staff who supervise them.
International Journal of Police Science and Management, Vol. 11 No. 4, 2009, pp. 393-413. DOI: $10.1350 /$ ijps.2009.11.4.149 


\section{INTRODUCTION}

The 2008 independent audit of youth justice in England and Wales (Solomon \& Garside, 2008), paints as gloomy a picture of New Labour's youth justice system as did the previous Audit Commission Report (1996), more than a decade before, and under a Tory government. Most of the governmental targets have been missed, and the central aim of the youth justice system, set out in the Crime and Disorder Act 1998, 'to prevent offending by young persons' has yet to be achieved (Solomon \& Garside, p. 65). Within this overall context, Solomon and Garside's review includes a specific critique of the Intensive Supervision and Surveillance Programme (ISSP), which is the focus of our independent study.

The ISSP was introduced in England and Wales (E\&W) in 2001 and by 2005 it had 'become recognised as the most robust and innovative community-based programme available for persistent and serious young offenders' (Gray et al., 2005, p. 9). This view has now become accepted uncritically by some commentators (see for instance, Stephenson, Giller, \& Brown, 2007). However, we argue that a 91 per cent reconviction rate for a disposal aimed at the most serious young offenders (Gray et al., p. 136) does not offer effective rehabilitation, or public protection and reassurance. We therefore took the failure of ISSP in reducing overall reoffending as our starting point so that we could seek explanations for this disappointing performance. Consequently, we carried out an in-depth critical examination of ISSP within two very different Youth Offending Teams (YOT) throughout 2007 , primarily to explore the often overlooked views of staff and young offenders.

Below, we first review the international evidence for the effectiveness of all forms of 'intensive supervision'. We then present our own research findings on whether ISSP's poor results reflect poor implementation/ management (and can therefore potentially be 'fixed'), or whether ISSP is a conceptually flawed intervention that will not achieve its aims, no matter how well implemented and run.

\section{BACKGROUND AND KEY FEATURES OF ISSP}

ISSP was specifically designed to: bring structure to offenders' lifestyles; tackle their criminogenic factors; and focus on areas worst affected by street crime (Home Office, 2002). ISSP is used as an element of existing disposals, typically, with Detention and Training Orders, Supervision Orders and Community Rehabilitation Orders (Gray et al., 2005, pp. 27-28). Offenders should receive five core intervention modules including: education/training; restorative justice; offending behaviour; interpersonal skills; and family support; although other options can be offered.

The framework and delivery of the ISSP is highly prescriptive (Smith, 2007, p. 126). Participants can be subject to monitoring up to 24 hours/7 days a week and should be subject to at least one form of direct surveillance (tracking; electronic tagging; voice verification) or intelligence-led policing (Gray et al., 2005, pp. 28-29). Young offenders generally spend six months on ISSP, although there is now a 12-month version (see Sutherland, Taylor, Gray, Merrington, \& Roberts, 2007). The most intensive supervision phase ( 25 hours a week) is in the first three months, followed by a minimum of five hours a week and weekend support for a further three months (Gray, et al., pp.18-27).

ISSP targets: persistent offenders (those charged, warned or convicted of offences committed on four or more separate dates, who have received at least one previous community or custodial disposal); serious offenders (those who would be at risk of a 
custodial sentence of 14 years or more if they were adults); and those who are at risk of custody or secure remand due to repeat offending on bail (Youth Justice Board [YJB], 2002, p. 5).

The overall aim is to provide a demanding programme to reassure the public. The Youth Justice Board ${ }^{1}$ (YJB) therefore set three key objectives for the programme: to reduce the reoffending rate by 5 per cent; to tackle young offenders' underlying problems effectively; and to demonstrate that supervision and surveillance is undertaken consistently and rigorously (Gray et al., 2005 , p. 27). A further aim has since been added: to divert young offenders from custody and reduce the number of under-18s remanded or sentenced by 10 per cent (Gray et al., p. 27; YJB, 2003), although Francis Done, the current chair of YJB, has admitted that this was too ambitious.

Although ISSP is unique in the current English youth justice system, it is not the first community-based intensive supervision programme to be implemented, and there was a rich body of international and domestic evidence available, which we review below, to inform policy-makers prior to ISSP's introduction.

\section{EFFECTIVENESS OF INTENSIVE SUPERVISION IN THE COMMUNITY: THE INTERNATIONAL EVIDENCE BASE?}

'Evidence-based practice' has been a key discourse in UK criminal justice since the Inspectorate of Probation's (HMIP) seminal 'What Works' publications of 1998 (see Chapman \& Hough 1998; Ellis \& Underdown, 1998; Ellis \& Winstone, 2002). It is therefore reasonable to expect that the justification for, and design of, ISSP, is evidence based, and that it should take account of the long history of intensive supervision (ISP) evaluation in the US and UK. It is clear in reviewing these evaluations that intensive programmes vary greatly (Smith, 2003, p. 137), and there is no consensus on how much more supervision is required before the programme becomes 'intensive' (Enos, Homan, \& Carroll, 1999, p. 27). Furthermore, evaluators have, unsurprisingly, utilised various methodologies and sample sizes (Moore, Gray, Roberts, Taylor, \& Merrington, 2006, p. 31). We have therefore attempted here to take a broad, inclusive approach to ISP evaluative evidence, but also ensured that we have focused on applying the findings in the specific context of ISSP.

\section{Evidence from the USA}

ISP in the USA dates back to the 1960s for adult offenders, though it was most popular between 1985 and 1995. Every large probation area developed programmes of intensive supervision and/or surveillance (Petersilia, 1998) and by 1994 it was estimated that 120,000 offenders were on such programmes (Altschuler, 1998, Corbett \& Petersilia, 1994). Figure 1 summarises the many studies which have previously explored the effectiveness of intensive supervision. Many of these evaluations have utilised Random Control Trials (RCTs) and are therefore considered to be of 'gold standard' (Moore et al., 2006, p. 32) and of achieving the top rated 'level 5 ' for scientific methodological rigour on the scale adopted and disseminated by the Home Office (Friendship, Street, Cann, \& Harper, 2004, p. 7). It is important to consider that the results of all but one of these studies was available before the introduction of ISSP in E\&W in 2001 and, as a body of evidence, provide no support for the further adoption of intensive supervision.

Having established that there is no firm evidence base for the effectiveness of intensive supervision from the US (see also Sherman et al., 1997 for a comprehensive literature review), we then reviewed the equivalent evidence from the UK. 
Figure 1

Evaluations of intensive supervision programmes

studies from the US

(Adapted from Moore, Gray, Roberts, Taylor \&

Merrington, 2006

pp. 39-41)

\section{Programme}

Post-custody parole in New Jersey (Pearson, 1988)

Probation for youn offenders in Michigan (Barton \& Butts, 1990)

ntensive Probation in California: Contra Costa, Ventura and Los Angeles. (Petersilia \& Turner, 1990)

Intensive Protective Supervision Project (IPSP) in North

Carolina. (Land, McCall, \& Williams, 1990)

Post custody parole in Texas (Turner \& Petersilia, 1992)

Probation or parole for drug offenders in

Washington, Iowa, New Mexico, Georgia, \& Virginia (Petersilia,

Turner, \& Deschenes, 1992)

Intensive Supervision in Ohio County (Weibush, 1993)

Parole for young offenders in Colorado, Virginia \& Nevada (Weibush et al., 2005)
Sample size

554 ISP cases \& 130 matched comparison cases

Random Assignment of 326 ISP cases \& 185 control cases

Random assignment of 488 cases (ISP \& control)

Random assignment to IPSP or control group

Random assignment of 679 cases (ISP \& control)

Random assignment of 281 ISP cases \& 268 control cases

Comparison between ISP youth \& a matched group committed to the Ohio Department of Youth Services

Random assignment of 230 Intensive Aftercare Programme (IAP) cases \& 205 control case
Offender profiles

Current offences generally serious, most had one prior conviction, over half had a drug problem

Average age of 15.4 years, Average of 3.2 prior charges, Current charge 'quite serious' in approx. $50 \%$ of cases

More than half previously incarcerated. Nearly half had serious drug-abuse problems, three-quarters were at high risk of recidivism

Two-thirds of sample were 14 or younger. About 20\% had a prior referral for a status offence, \& 15\% had a prior referral for a delinquent offence

Average age of 31 years. Average of 8-9 prior arrests \& 6-8 prior convictions. $85 \%$ had served at least two prison terms. Nearly all classified as high risk

Mean ages ranged from 26-30 years across the sites. More than twothirds were of high or moderate risk. The majority were drug dependent

Juvenile felony offenders

The young offenders were at high risk of reoffending. In Nevada, two-thirds had 11 or more prior referrals, $80 \%$ had a prior commitment to secure care, \& 55\% were gang members
Mix of surveillance and treatment techniques

A 1 year programme with an average of 10 contacts per month

(Behavioural supervision, individual counselling, school placement assistance, social skills training)

Surveillance-orientated and participation in rehabilitative programmes

Enhanced supervision (several contacts per day)

9- to 12-month programme with an average of $6.5 \& 4.8$ contacts per month

The average contacts ranged from three to twenty three (surveillance, urine analysis, drug treatment \& counselling)

Small IAP specific caseloads \& individualised case planning
Outcomes

$41 \%$ ISP cases recalled to prison before completion. After 2 years, $12 \%$ of ISP group had an arrest compared with $23 \%$ of comparison cases. However, numbers of participants were not matched

$78 \%$ of participants reappeared in cour during 2-year follow up

In a 1-year follow-up period, $40 \%$ had technical violations \& a third had new arrests. There was no significant difference between ISP \& control groups

No long term difference between groups over 3 years

ISP was not associated with a reduction in arrests \& there was an increase in technical violations

In a 1 -year follow up period, $11 \%$ to $48 \%$ of ISP offenders were arrested for new crimes. No significant differences were found between the ISP and control groups

No significant differences in recidivism among the groups \& ISP group had higher technical violations than routine probationers or parolees

No significant differences between groups 


\section{Evidence from the UK}

Some commentators have suggested that English intensive supervision programmes are more advanced than that of their foreign counterparts. For instance Moore et al. (2006, p. 42) state that, 'Generally speaking ... programmes in England and Wales have tended to be of greater intensity, and the need for some form of treatment/ rehabilitation has been more consistently applied'. It would therefore be expected that the overall results from UK ISPs would be more positive than those from the US. However, as shown in Figure 2, this is not

\begin{tabular}{|c|c|c|c|c|}
\hline Programme & Sample size & Offender profiles & Programme structure & Outcomes \\
\hline $\begin{array}{l}\text { Intensive Matched } \\
\text { Probation and After } \\
\text { Care Treatment } \\
\text { (IMPACT) (Folkard, } \\
\text { Smith \& Smith, 1976) }\end{array}$ & $\begin{array}{l}\text { Random assignment of } \\
244 \text { experimental cases } \\
\text { \& } 161 \text { control cases }\end{array}$ & $\begin{array}{l}\text { Two-thirds to three- } \\
\text { quarters were aged } \\
\text { 17-29. Many had been } \\
\text { placed on probation } \\
\text { before }\end{array}$ & $\begin{array}{l}\text { Officer caseloads } \\
\text { reduced from } 40-45 \\
\text { cases to approximately } \\
20 \text { cases. Emphasis upon } \\
\text { situational treatment } \\
\text { with more direct } \\
\text { involvement in the areas } \\
\text { of family, work and } \\
\text { leisure }\end{array}$ & $\begin{array}{l}\text { No significant } \\
\text { differences in } 1 \text { \& } 2 \text { year } \\
\text { reconviction rates. This } \\
\text { study was instrumental in } \\
\text { raising doubts about the } \\
\text { effectiveness of intensive } \\
\text { supervision (Raynor \& } \\
\text { Vanstone, 2002) }\end{array}$ \\
\hline $\begin{array}{l}\text { Hereford \& Worcester } \\
\text { Young Offender Project } \\
\text { (YOP) (Roberts, 1989) }\end{array}$ & $\begin{array}{l}\text { YOP sample }(n=53) \& \\
2 \text { comparison groups } \\
\text { who received custody } \\
(n=56 \& 51)\end{array}$ & $\begin{array}{l}\text { Offenders } 17-20 \text { yrs, all } \\
\text { unemployed. }\end{array}$ & $\begin{array}{l}\text { Intensive programme of } \\
\text { supervision \& activity } \\
\text { (social skills training, } \\
\text { group work etc) }\end{array}$ & $\begin{array}{l}\text { Reconviction results } \\
\text { show that there was a } \\
\text { short-term benefit for } \\
\text { the } 2 \text { custodial groups }\end{array}$ \\
\hline $\begin{array}{l}\text { Intensive Probation (IP) } \\
\text { for young adult } \\
\text { offenders (Leeds) } \\
\text { (Brownlee \& Joanes, } \\
\text { 1993; Brownlee, 1995) }\end{array}$ & $\begin{array}{l}227 \text { IP cases compared } \\
\text { with a custodial group } \\
\text { of unknown size }\end{array}$ & Unknown & $\begin{array}{l}\text { An eight week } \\
\text { individualised } \\
\text { programme (One-to-one } \\
\text { counselling, offending } \\
\text { behaviour \& social skills } \\
\text { sessions) }\end{array}$ & $\begin{array}{l}73 \% \text { of a small sub- } \\
\text { sample }(n=45) \\
\text { reconvicted over a two- } \\
\text { year follow-up period }\end{array}$ \\
\hline $\begin{array}{l}\text { Intensive Probation (IP) } \\
\text { for young adult } \\
\text { offenders (Mair et al, } \\
\text { 1994) }\end{array}$ & $\begin{array}{l}1,677 \text { offenders referred } \\
\text { to IP. No comparison } \\
\text { group }\end{array}$ & $\begin{array}{l}51 \% \text { had more than five } \\
\text { previous convictions \& } \\
54 \% \text { had previous } \\
\text { experience of custody }\end{array}$ & $\begin{array}{l}\text { Individualised } \\
\text { programmes involving } \\
\text { frequent contact with a } \\
\text { project worker \& an } \\
\text { emphasis upon } \\
\text { confronting offending } \\
\text { behaviour }\end{array}$ & $\begin{array}{l}\text { Inconclusive: IP worked } \\
\text { well in some areas and } \\
\text { not in others }\end{array}$ \\
\hline $\begin{array}{l}\text { Intermediate Treatment } \\
\text { (IT) and Heavy-End } \\
\text { Intermediate Treatment } \\
\text { (HEIT) for young } \\
\text { offenders (Bottoms, } \\
\text { 1995) }\end{array}$ & $\begin{array}{l}103 \text { Heavy-End IT } \\
\text { (HEIT) cases, } 40 \text { other } \\
\text { IT cases, } 141 \text { custody } \\
\text { cases \& } 142 \text { straight } \\
\text { Supervision Order cases }\end{array}$ & $\begin{array}{l}\text { Mean age was } 15.7 \\
\text { years. For the HEIT } \\
\text { group, the average } \\
\text { number of charges/ } \\
\text { convictions in the prior } \\
14 \text { months was } 7\end{array}$ & $\begin{array}{l}\text { Varied between sites, } \\
\text { however emphasis upon } \\
\text { tracking with weekly } \\
\text { meetings. (Group and } \\
\text { individual work, social } \\
\text { skills \& various constructive } \\
\text { activities) }\end{array}$ & $\begin{array}{l}\text { There was no 'automatic } \\
\text { or necessary } \\
\text { relationship' between } \\
\text { HEIT \& custody levels }\end{array}$ \\
\hline $\begin{array}{l}\text { ISSP Kent (Variant } \\
\text { forerunner to ISSP) } \\
\text { (Little et al., 2004) }\end{array}$ & $\begin{array}{l}\text { Randomly allocated to } \\
\text { ISSP or standard } \\
\text { services. } 24 \text { ISSP cases } \\
\& 24 \text { control cases \& } 31 \\
\text { matched cases }\end{array}$ & $\begin{array}{l}\text { Offenders } 15-17 \text { years } \\
\text { old: offenders charged } \\
\text { or cautioned on three } \\
\text { or more occasions with } \\
\text { a } 12 \text {-month period with } \\
\text { an imprisonable offence }\end{array}$ & $\begin{array}{l}\text { Multi-systemic, four } \\
\text { compulsory components } \\
\text { \& three ancillary } \\
\text { components }\end{array}$ & $\begin{array}{l}87 \% \text { reconvicted after } 2 \\
\text { years \& no differences } \\
\text { between groups }\end{array}$ \\
\hline $\begin{array}{l}\text { Probation for young } \\
\text { adult offenders: } \\
\text { Intensive Control \& } \\
\text { Change Programme } \\
\text { (ICCP) (Partridge et al., } \\
2005 \text { ) }\end{array}$ & $\begin{array}{l}433 \text { ICCP cases. No } \\
\text { comparison group }\end{array}$ & $\begin{array}{l}\text { Offenders had an } \\
\text { average of } 27 \text { previous } \\
\text { convictions, \& a } \\
\text { medium to high risk of } \\
\text { reoffending. }\end{array}$ & $\begin{array}{l}\text { A minimum of } 25 \text { hours } \\
\text { of contact per week for } \\
\text { first three months } \\
\text { (mandatory curfews with } \\
\text { electronic tagging, } 5 \text { core } \\
\text { supervision components, } \\
\text { encompassing behaviour } \\
\text { programmes, supervision } \\
\text { and training etc) }\end{array}$ & $\begin{array}{l}26 \% \text { of offenders had } \\
\text { their orders revoked or } \\
\text { terminated \& a further } \\
27 \% \text { breached the } \\
\text { programme }\end{array}$ \\
\hline
\end{tabular}

Figure 2

Evaluations of intensive supervision programmes in England \& Wales (Adapted from Moore, Gray, Roberts, Taylor \& Merrington, 2006, pp. 58-60) 
the case. Again, the results of most of these evaluations were available before the introduction of ISSP in E\&W in 2001.

In short, the findings from both sides of the Atlantic are overwhelmingly negative, with high reconviction and breach rates. Indeed, Fulton, Latessa, Stichman, and Travis (1997) argue that the blanket conditions placed on ISP offenders, plus stringent breach procedures, actually compound prison overcrowding and increase costs. This suggests that the ISSP in E\&W may even work against the YJB's own performance measure of reducing youth custody. Subsequent commentators have stressed the need to provide 'quality contact', not just more 'supervision contact' (Goodstein \& Sontheimer, 1997; Nee \& Ellis, 2005).

Given the poor performance of ISPs and the wealth of evaluations evidencing this, the obvious question is: on what evidence was the introduction of ISSP in 2001 based? According to Green, Grove, and Martin (2005), the answer appears, worryingly, to be: on the results of a very small pilot scheme, that is, the 'Rotherham Intensive Supervision, Support and Advocacy Programme' (RISSAP), carried out in August 2000. RISSAP evaluated 27 young offenders who were convicted of 160 offences in the 9 months before the intervention, but committed only 47 offences during the programme supervision period. The full evaluation of this small intervention has never been published. However, Green et al. claim that in the final analysis, 35 offenders in the programme group were compared with 18 offenders in a 'comparison' group, and that 7 per cent fewer of the former had reoffended. Given the weight of evidence of so many evaluations of much higher quality outlined above, it is not hard to accept Green et al.'s criticism that the RISSAP evaluation was not scientifically rigorous enough as a basis for the national, multi-million pound roll-out of ISSP.
Despite the complexities and differences of the evaluations profiled above, it seems clear that the balance of the evidence is overwhelmingly against intensive supervision, however it may be configured. As Gendreau, Goggin, Cullen, and Andrews (2000, p. 11) argue, 'ISPs have had little effect on offenders' future criminal activity above what would occur by chance'. In addition to this evidence, by 2001 there were many separate international warnings that intensive supervision was likely to be abandoned due to its poor performance (Byrne, 1990; Clear, Flynn, \& Shapiro, 1987; Stone \& Fulton, 1995). Proponents of ISSP might argue that RISSAP represented a new, youth-focused approach that was not bound by previous models of intensive supervision. However, the results of the YJB's own independently commissioned evaluations, as outlined below, suggest otherwise.

\section{YJB COMMISSIONED EVALUATIONS OF ISSP}

On the back of RISSAP, ISSP was introduced in 2001. The independent evaluators themselves, Moore et al. (2006, p. 71), state that 'the [ISSP in E\&W] is far more intensive than many of its predecessors and seeks to deliver an appropriate balance between control and care'. One would therefore expect their findings to be positive. However, YJB press releases aside, this is not the case.

The YJB commissioned an independent impact evaluation of ISSP in two stages (Gray et al., 2005, p. 19; Moore et al., 2004), covering the first 41 schemes across England and Wales. The design and content of these early ISSPs varied significantly, itself a challenge to the evaluation (Gray et al., p. 9). In reading these evaluations, and their related press releases, it is often hard to distinguish between public relations content and academic evaluation. Indeed, while a 
2004 press release claimed ISSP had successfully reduced reoffending (YJB, 2004), this was clearly a partial and misleading view, as the evaluation itself showed ISSP did not outperform any of the comparison samples (Moore et al.; Gray et al.).

\section{Sampling and comparison sizes}

Sampling for the YJB evaluation was particularly difficult, due to the severe and persistent nature of the target offenders, who could only be included in the analysis if they had been at liberty for 12-24 months. This resulted in a loss of cases and it must be doubted whether the number was sufficient.

The main impact findings from the independent ISSP evaluations are outlined below.

\section{The impact of the ISSP on the use of custody}

ISSP was not launched as an alternative to custody, but was later given that aim (YJB, 2003, p. 3). Between April 2000 and December 2004, YJB's national data showed a 2.1 per cent reduction in juvenile custody. However, during the evaluation period, reductions took place in both ISSP and non-ISSP areas, probably due to a range of national policies and initiatives to reduce juvenile imprisonment (Gray et al., 2005, p. 10).

\section{Reconviction rates}

The overall ISSP 12-month reconviction rate was 89 per cent, and the 24-month

Table 1: Total sample sizes of ISSP cases, and comparison groups: 12 and 24-month evaluations

ISSP Comparison

12-month reconviction sample $\quad 2,842 \quad 1,112$

24-month reconviction sample $\quad 943 \quad 510$

Source: Gray et al. (2005, p. 51).
Table 2: Actual and expected 12-month reconviction rates with comparison sample

\begin{tabular}{llll}
\hline & $\begin{array}{l}\text { Expected } \\
\text { rates }\end{array}$ & $\begin{array}{l}\text { Actual } \\
\text { rates }\end{array}$ & $\begin{array}{l}\text { Actual rates of } \\
\text { comparison } \\
\text { sample }\end{array}$ \\
\hline Bail ISSP & $80 \%$ & $92 \%$ & NA \\
SO/CRO ISSP $\ddagger$ & $79 \%$ & $88 \%$ & $84 \%$ \\
DTO ISSP & 80 & 91 & 76 \\
All ISSPs & 79 & 89 & - \\
\hline
\end{tabular}

Notes:

$\ddagger \mathrm{SO}=$ Supervision Order; $\mathrm{CRO}=$ Community

Rehabilitation Order; DTO=Detention and Training Order. Source: Gray et al. (2005, p. 27).

reconviction rate was 91 per cent (Gray et al., 2005, p. 27). These rates varied according to the type of intervention (Table 2), but such results can, at best, be regarded as very poor, and at worst, as a failure. It was not possible to compare actual and expected rates over two years because at that time Asset $^{2}$ was only validated to predict 12-month reconviction rates (Gray et al., pp. 59,136$)$.

\section{Reductions in frequency and seriousness of offending}

Gray et al. (2005) and YJB press releases focused more heavily on ISSP reductions in the frequency (40 per cent) and seriousness (13 per cent) of offending, than on the disappointing overall reoffending rate above. Indeed, the results looked initially promising. However, when compared with the community comparison groups used by Gray et al., ISSP performed slightly worse. Even the evaluators noted that these reductions were partly attributed to 'regression to the mean' (see Cook \& Campbell, 1979) and partly to not being able to establish good comparison groups (Gray et al., p. 51). This is hardly strong enough evidence for a ringing endorsement of the impact of ISSP. 
Table 3: Reductions in frequency and seriousness of offending: results after 12 and 24 months with comparison sample

\begin{tabular}{lllll}
\hline & All ISSPS 12 months & $\begin{array}{l}\text { Community comparison } \\
12 \text { months }\end{array}$ & All ISSPs 24 months & $\begin{array}{l}\text { Community comparison } \\
24 \text { months }\end{array}$ \\
\hline Frequency & $-40 \%$ & $-42 \%$ & $-39 \%$ & $-39 \%$ \\
Seriousness & $-13 \%$ & $-16 \%$ & $-13 \%$ & $-15 \%$ \\
\hline
\end{tabular}

Source: Gray et al. (2005, pp. 61-69).

\section{Effectiveness of ISSP as perceived by staff, young offenders and their families}

Evaluators also focused on the positive feedback from 173 young offenders, 33 parents and 144 staff members, where there was praise for the capacity of ISSP staff to identify and focus on welfare needs (Gray et al., 2005, p. 125). However, the evaluators also found examples of homelessness, unmet mental health and special educational needs, poor social work intervention, and obstacles with education, training and external services (Gray et al., p. 141).

\section{2-month duration ISSP 'pilot study'}

A longer, 12-month version of ISSP was piloted later in 11 areas, showing an even lower completion rate (32 per cent) than the 6-month version (42 per cent) (Sutherland et al., 2007, p. 13). Of most concern in terms of public protection, the average number of non-compliances per offender was extremely high at 27 (Sutherland et al., pp. 100-101).

\section{The YJB's own findings on ISSP effectiveness}

Overall, the reconviction results do not show that ISSP outperformed any of the comparison samples (Gray et al., 2005, p. 136). With low completion rates, high reconviction rates, and no concrete evidence of success, it is surprising that the scheme has not received more criticism from academics (Green et al., 2005) and the press (eg, Slack, 2007). The YJB's own evaluations offer a significant contribution to the evidence base on intensive supervision of young offenders in England and Wales. However, they in no way offer a departure from the findings of the high quality international evidence base outlined above. Indeed, in less prominent parts of their published reports, the independent evaluators have stated, 'even though a number of methods were used, it proved difficult to establish if the ISSP has a beneficial impact on offending' (Moore et al., 2004, p. 321). In the later study, they also noted that 'overall, the results to date at both 12 and 24 months do not show that collectively ISSP outperformed the comparison samples' (Gray et al., 2005, p. 136). The positive gloss put on these results both in the evaluation reports and in the YJB press releases was easy to rub off. In The Times, Gibb and Ford (2005) argued unequivocally that, "when the main show is such a staggering flop ... it takes some cheek to crow about the lighting'.

There is little doubt, on the balance of the evidence presented so far, that the YJB should have been aware of the likely ineffectiveness of ISSP on reoffending. But should it not also have considered the ramifications of ISSP for public protection? It is very striking that we could not find any discussion of public protection on the YJB website up to September 2007. Therefore, we decided to focus our own independent 
empirical research on: the extent to which ISSP's poor performance can be attributed to a flawed concept of intervention, or to implementation failure and/or poor practice; and the extent to which public protection is considered in the supervision process.

\section{ISSP IN PRACTICE: 2 YOT AREA CASE STUDIES}

The findings from evaluations of intensive supervision in general, and ISSP in particular, indicate that there is a gap in knowledge. We know ISSP performs relatively poorly in terms of reducing reoffending, but we do not know why. We therefore negotiated access to two contrasting YOTs, and designed an in-depth primary research study to address this.

\section{Methods}

The bedrock of our triangulated approach (see Robson, 2002) was in-depth participant observation, for six months in mid2007 , by one of the authors working as a part-time ISSP supervisor in YOT Area 1. This yielded a considerable depth of qualitative data and represents a new point of comparison with previous studies. Since participant observation is open to potential subjectivity and lack of generalisability, we also negotiated access to the additional, much larger YOT Area 2. We then carried out semi-structured interviews and administered questionnaires with both ISSP staff and ISSP participants in both YOT areas. All methods were integrated sequentially, so that the literature review, personal practice and observations were used first to compile semi-structured interview schedules, and then questionnaires (see Table 4 for a summary).

We felt that, within available resources, this was the best approach to studying whether or not the ISSP design is well matched to its overall aims. Although the
Table 4: Number, type of participants and methods used by YOT area

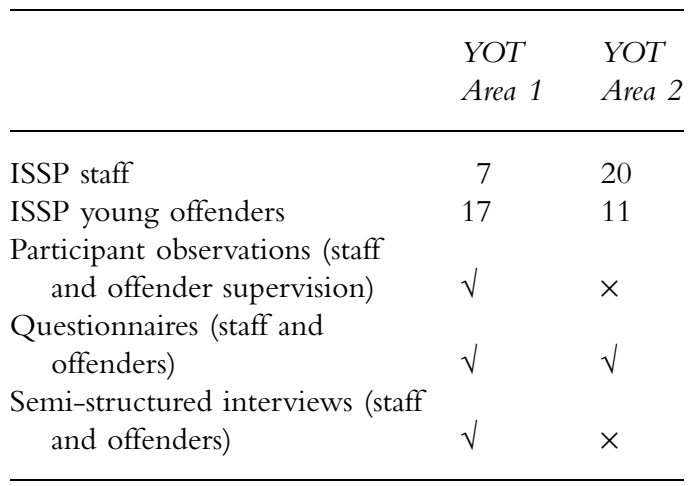

numbers are not large, they represent a large proportion of staff and offenders in the YOT areas. It is also important to stress that this is not a direct comparison of two YOT areas, as they are of differing size, management structure and operation. However, the inclusion of two YOTs adds rigour to the research that analogous published studies on YOT intervention often do not provide (eg, Burnett \& Appleton, 2004).

We were keen to ensure that the offender's voice was central to the research process. From Matza (1969) onward, there have been criticisms that this is relatively rare. Most recently, Moore (2007) recommended that more attention should be paid to offenders' perceptions of their own likelihood of reoffending. It was striking that our young offenders had a very positive approach, both to our research approach and instruments, but especially to being asked for their opinions. We had anticipated some difficulties with the more structured questionnaires, but the offenders were generally enthusiastic and approached the task with detachment and honesty.

\section{Findings}

The separate questionnaires for staff and for offenders were developed, as far as possible, with 'matched' statements. These statements were in a logical, progressive order, and 
were designed so that groups of four to five questions were combined to form broader ISSP topic section scores under the following key headings: ISSP as a concept; organisation and communication; targeting appropriate offenders; addressing individual needs; public protection by surveillance; public protection by preventing further offending; impact measures; breach proceedings; ISSP as an alternative to custody; and reasons for non-completion. Respondents were also given a chance to provide further qualitative information. To avoid anticipated difficulties with offender literacy and attitudes to educational work, we used a Likert scale-based questionnaire largely as the basis of an 'interview'. All data have been regularised so that a score of 7 represents the most positive response and a score of 1 the least.

\section{Conceptualising ISSP: organisation and communication}

The 28 young offenders were largely positive about ISSP as an idea for intervention $(M=5.5)$ as were the 27 ISSP staff $(M=6.4)$.

Offenders were then asked about ISSP 'organisation and communication'. This was measured by six statements, on whether: ISSP was fully explained at the outset of the programme; offenders understood what was expected of them; organisation had been good; offenders felt able to discuss problems with ISSP staff; offenders were able to communicate with their caseworkers; and whether ISSP was of appropriate length. The overall mean score for the 28 young offenders was 5.3, indicating that YOT service delivery and communication was rated as good.

These results would suggest that ISSP practitioners are performing well, and that, as a general principle, the ISSP approach is valued by both participants and staff alike. We therefore need to look elsewhere for an explanation of the overall poor performance of ISSP.

\section{ISSP targeting of appropriate offenders and addressing individual needs}

Offenders responded to one statement regarding their suitability for an ISSP and they responded with a weakly positive mean score of 4.6. However, seven respondents qualified this by saying that their offences were so severe that they should have received an immediate custodial sentence, eg, 'I have done really bad stuff and I should have gone to custody'. The ISSP staff produced a very similar weakly positive score of 4.8. However, their qualitative responses had a different focus. Age was the common factor for 10 of the 27 practitioners: eg,

A lot of times we have had older offenders, say 17ish. By then, I just think it is too late. They know the system more than I do and it is impossible to change them.

By the time ISSP is given, the young person is so into offending that stopping them from reoffending, or even slowing down the offending rate, is unlikely.

Young offenders were then asked to respond to whether ISSP addresses their individual needs. An overall negative mean rating of 3.2 was explained by some of their comments: four different 17-year-old offenders made very similar points about the age-inappropriate intervention packages available:

I was given a school bullying pack to do when I was not even at school; the interventions are all based on the same thing.

I have to do teen talk packs which are really childish and nothing to do with me. 
I was made to play with plastic men and told to move them through an imaginative grand chamber of feelings. I was embarrassed coz I was nearly 18.

This is a very serious issue for programme delivery. The mean age of the 17 young offenders from Area 1 was 16.4 (higher than the joining age of the British Army) and the age range was narrow, from 15 to 17 , with a profile of offences including grievous bodily harm, robbery and burglary. Much of the programme content was designed for a younger age group, and with an uncertain evidence base. Supervision experience showed them to be very streetwise, experienced in youth justice and sensitive to being 'talked down to as kids'.

Young offenders also noted the low level of participatory effort required, eg, 'You just go there and sit down, get spoken to and then go home. The hardest part of the supervision is getting out of bed.'

The overall YOT staff response to the same issue was a straight neutral score of 4 , but analysis shows that this masks the fact that staff in Area 1 had a relatively positive view (5.1), while staff in Area 2 had a weakly negative view (3.8) (see Table 5).

Oddly, whilst the young offenders' views were weakly negative in Area 2, it is not very distant from the almost neutral staff view (3.8), but in Area 1, there is a large gap between staff's positive view (5.1) and the young offenders' very negative one (2.4). Whilst the numbers are small, it seems that

Table 5: ISSP addressing individual needs: mean scores by YOT area and respondent type

\begin{tabular}{llllll}
\hline Participants & $\begin{array}{l}\text { Area 1 } \\
\text { mean }\end{array}$ & (n) & $\begin{array}{l}\text { Area } 2 \\
\text { mean }\end{array}$ & (n) & $\begin{array}{l}\text { Combined } \\
\text { mean }\end{array}$ \\
\hline Staff & 5.1 & (7) 3.8 & (20) 4.0 \\
Offenders & 2.4 & (17) 4.5 & (11) 3.2 \\
\hline
\end{tabular}

there is likely to be a much larger disagreement over the extent to which staff and offenders think that ISSP addresses individual needs in many different YOT areas, and that this variation will be missed by a 'national' study. If ISSP is to be rescued (and we contend that it cannot be), it will require a much greater evaluative focus on variations in practice and performance by area, and controlling for any potential data manipulation.

With these general issues established, we turned our attention to the extent to which ISSP offered genuine public protection from serious and persistent offenders.

\section{Public protection through ISSP surveillance}

Young offenders were asked to respond to two statements about the overall surveillance element of the programme: "whether YOT staff knew their whereabouts at all times'; and, 'whether they felt ISSP resulted in intensive monitoring'. The response scores were very similar and these were combined to provide an overall 'ISSP surveillance' rating. The resulting low mean of 2.6 is a disturbing finding in terms of the level of public protection provided. Young offenders clearly thought they were subject to a low level of scrutiny and the qualitative responses suggest why, eg, 'The staff know where I am for only a few hours a day and then they don't know shit'.

Criticisms about the effectiveness and appropriateness of tagging are not new. There has been widespread and sustained academic criticism of this surveillance element (see Shute, 2007), and the press often focus on catastrophic youth justice results (Maynard, 2007). However, we still found a higher level of tagging inadequacies than anticipated, with nine offenders questioning this surveillance element, eg:

Tag would only work if someone was to come and get us back straight away every 
time we breached it, but nothing happens for ages.

Tags are so easy to get off your ankle and they are shit anyway; nobody knows where I am when I leave my house even when I have it on.

YOT staff were asked to respond to an equivalent statement on whether they felt young offenders were 'intensively monitored enough to ensure that they did not have the opportunity to reoffend'. They answered with a weakly negative mean score of 3.6, and it is clear from their qualitative answers that they were less focused on the tagging element and more concerned about the overall level of surveillance, eg:

It is impossible to monitor to a sufficient level unless we are standing beside them 24 hours a day. If they want to reoffend they will.

Let's face it; the ISSP is not intensive at all, 25 hrs a week isn't even a part-time job.

National standards say that we should have face-to-face contact everyday. This cannot be done in reality due to staff and resource constraints, especially not on a Sunday, and I don't know any YOT that can facilitate such standards. There is the YJB official line, and then there is what everyone does.

There are also practical difficulties, suggesting that the ISSP design is not appropriate in either area. In Area 1, a small team of ISSP staff cover a large geographical area:

It is normal to drive over 50 miles to see an offender. We are chasing the kids and they don't have to put much effort in. There is not enough emphasis that this is an official order. How can we intensively supervise someone from such a distance?
There was also staff frustration with regard to tagging breaches and this serves as a check against potential exaggeration and bravado from the young offenders. With similar overtones to HM Inspectorate of Probation's (2005) investigation into the YOT supervision of Peter Williams, who was involved in the murder of Marian Bates in 2003, one ISSP manager stated:

To the private security staff, offenders are just names on a computer and there is no sense of responsibility. It is important for us to know where all our kids are for public safety. [Named security company] just don't let us know anything, and it has gone on for years.

Whilst the tag is a key element of what the YJB presents as consistent and rigorous surveillance to reassure the public (Gray et al., 2005 , p. 27), in our research areas it appears that tags represent a challenge to be managed effectively, rather than a punishment or restraint. The most concerning aspect of tagging is the powerlessness of the YOT in the immediate aftermath of a breach. Any technological difficulties are secondary to those caused by an ineffective information management process and the combined inability to react quickly.

\section{Public protection through preventing further offending}

Young offenders were also asked to respond to a statement on 'whether the ISSP protects the public from offending'. The result was a very negative mean score of 2.0. The following comments typified the general feeling:

The ISSP does not protect the public for shit.

It don't stop me from doing any criminal shit, so it don't protect no one.

This is not surprising, perhaps, given the 
findings on ISSP surveillance above (and on ISSP impact below).

These findings suggest that the ISSP is having neither the desired incapacitative effect, nor the claimed consistent and rigorous supervision and surveillance (Gray et al., 2005, p. 27), and therefore offers little guarantee of protection to the public.

Eight offenders stated that they offended to a high degree while under ISSP supervision, eg:

Since being on the ISSP the last three times, I have committed over a hundred offences, mostly commercial burglaries.

What good does it do? ISSP takes you out of the community for a few hours and then chucks you straight back.

The ISSP is not a big part of my life. You just tell YOT workers what they want to hear and then it's well easy to get through a session, even though it's bullshit! After the meeting you just carry on as normal.

The YOT supervisors' overall response $(M=3.3)$ indicates that they would not be too surprised at this picture and are perhaps realistic about ISSP impact.

More worrying still was the fact that in staff meetings to review individual cases, public protection was rarely discussed. Indeed, in the case of one young offender, convicted of a serious robbery, an ISSP supervisor stated that: "We need to wait for him to reoffend and then he will go into the adult system'.

It seems that the bureaucratic exigencies of the job (Ellis \& Boden, 2005) and a rather battle-weary attitude mean that risk to the public is largely unacknowledged in the ISSP supervision process. The following comment typified the general feeling of ISSP supervisors:

We are dealing with severe offenders and it is inevitable that they are going to reoffend, usually multiple times. We are powerless to stop them because we are only with them for a small amount of time.

\section{ISSP impact on reconviction}

From the outset, we knew that ISSP reconviction rates were extremely high, ${ }^{3}$ and that seriousness and frequency of reoffending, while reduced, were higher than in the comparison groups (Gray et al., 2005). However, ISSP staff argued that a focus on reconvictions alone may not provide a fair reflection of ISSP success. We therefore also explored other measures of ISSP success that were derived from YOT staff and participants' views expressed in the observational work.

The offender questionnaire used five statements about the overall impact of ISSP supervision. For most of this analysis, these were combined into a single impact variable. For offenders, the overall impact mean score was 3.1, indicating a low overall perceived impact. The component mean scores were telling here: "whether ISSP had stopped further offending' (2.8); 'whether ISSP will improve life chances' (2.9); 'whether participants benefited in any way from the ISSP' (3.2); 'whether ISSP had a positive impact upon offenders' attitudes to offending' (3.4); and 'whether ISSP had a positive impact on behaviour' (3.5). As one, not untypical offender stated: 'You lot won't fucking change me, I am a criminal and a fucking good one. I hang with my boys and this is what we do, we are gangsters'.

The staff questionnaire carried five comparable statements about the impact of the ISSP, with a weaker overall negative mean impact score of 3.9. While YOT staff felt that ISSP was a relatively positive approach to improving the life chances of offenders (4.8), none of the other responses went above neutral (4). Indeed, there were clearly negative ratings for whether ISSP stops young people from offending (3.0) and for 
whether ISSP effectively controls the behaviour of young offenders (3.5).

Although expressed differently, the staff's views were largely similar in content to those of the young offenders. The following comments, from two managers, suggest little naivety about ISSP: 'If you think the ISSP can stop these offenders from further offending then you are mistaken, but we can give them a chance', and 'ISSP is not a miracle cure and it cannot stop offending'.

We were unable to access Area 1 reconviction figures, so it is important to note that: 10 of the 17 offender respondents here failed to complete the ISSP; three were still under supervision: and of the four that completed, three have subsequently reoffended. Area 2 achieved slightly lower reconviction rates than the YJB national study: 82 per cent for a cohort tracked for 12 months in 2005 , and 85 per cent for a cohort tracked for 24 months.

\section{ISSP breach proceedings}

Tagging aside, strict enforcement and compliance are key elements stressed by YJB in making ISSP effective for public protection and reassurance. Indeed, ISSP has fast-track arrangements so that breaches are dealt with quickly (YJB, 2002, p. 8). Hedderman and Hough's (2004) research on adult offenders supports this approach, while others have questioned the effectiveness of such managerialist approaches to enforcement (see Ellis, 2000). Indeed, Hearnden and Millie (2004) later found that stricter enforcement was not synonymous with better results, and this again raises the question of what enforcement is expected to achieve. As noted above, stricter enforcement may simply increase the proportion of young offenders in custody (Fulton et al., 1997).

We therefore asked offenders and ISSP staff about the extent to which enforcement is a deterrent, and whether it was effective in ensuring compliance with ISSP conditions. We then also asked them about their attitudes to custody.

The results showed that offenders 'were concerned about receiving a breach' (4.8), they 'felt that it mattered if they missed appointments' (5.3) and they were clear that 'there would be repercussions if they were breached' (4.5). This gives a relatively encouraging picture of the deterrent and retributive potential of enforcement processes, and of offenders' understanding of the terms of ISSP. However, when offenders responded to the statement about the 'promptness of breach action leading to a return to custody', the mean score was 3.2. It seems that a high potential fear of enforcement action is being undermined by ineffective procedural application. Offenders' qualifying comments also confirm that fast-tracking of breaches remains aspirational:

Everyone knows how long it takes to get breached on the ISSP and everyone plays the system.

You get a warning and nothing happens for ages. I have missed loads of appointments and I reckon that I have had about 8 final warnings!

Interestingly, the YOT staff thought that they enforced ISSPs effectively, with a mean score of 5.1. Their qualifying comments suggest that delays were caused by the time it takes to get a court date: 'It's not uncommon for it to take two to three weeks to get a court date, which is not good if you have a high risk offender within the community.'

Others, however, had ambiguous attitudes to breach action, and the range of approaches was very similar to findings on the level of discretion used in adult probation supervision over a decade ago (see Ellis, Hedderman, \& Mortimer, 1996):

What do you define as a breach? I deal 
with kids that leave home for days on end, and I don't constitute a few hours late as a breach!

If we breached kids for missing appointments every time, none of them would get through the programme.

From a welfare perspective, this may well be laudable, but from a justice perspective (Canton \& Eadie, 2005, p. 147), it leaves further doubts about public protection and helps explain Sutherland et al.'s (2007, pp. 100-101) finding, referred to above, of a mean of 27 non-compliances per offender.

\section{ISSP as an alternative to custody}

Offenders were asked whether they 'perceived the ISSP to be a good alternative to custody'. The resulting overall mean score (5.4) seemed very positive, suggesting that despite the low impact, surveillance, and public protection scores, offenders rated ISSP highly. However, the qualitative findings show that offenders were responding to what was the most attractive option to them. The following comments typified the general feeling of ISSP respondents:

The ISSP is nicer than custody and everyone is going to say that. The ISSP is good for us, because we can see our mates.

I got away with it when I got the ISSP and everyone says the same thing.

When talking about the achievement of ISSP aims, rather than offender preferences, six offenders actually argued that custody was more likely to be beneficial than the ISSP in reducing reoffending in the long term:

In prison they work on the future, but on the ISSP they concentrate on the past. Prison has an impact on your personality and it sticks in your head.
I have done better in prison because the boundaries are clear. I also got qualifications inside and I have got none on ISSP. I think the ISSP is pointless because you don't come away with anything.

The observational work showed that there was a fairly complex discourse at work here. In comparing ISSP reconviction rates with those of youth custody (just below 80 per cent for the 2004 cohort (Whiting \& Cuppleditch, 2006)), there is little to choose. It would be easy, therefore, to discount offenders' views. However, what they were advocating was a more nuanced and instrumental approach, typically:

Prison is better because it takes you out of your own town where you always get into trouble $\mathrm{coz}$ of your mates. The ISSP keeps you in the same place. I reckon better education in prisons would be better or just teach us a trade.

It was clear that the ideal for these offenders was to be taken out of their current environment, to be taught job-related skills, and crucially, to be 'relocated' away from their original area, with continued support from YOT, or equivalent staff. The question remains here as to whether 'custody' is the likely or necessary way to achieve this. It seems that current community provision through the ISSP is simply not addressing offenders' needs, but could be, for instance, in the form of 'intensive fostering' or in alternative sanctions available, such as 'unpaid work'. The participant observation threw up many conversations involving staff and offenders, where there was a general agreement that 'unstructured lifestyle' was the biggest reason for non-completion of ISSP. The key question then becomes: why is ISSP failing to deliver on its 'promise' of bringing organisation to an offender's routine? (YJB, 2002, p. 5). It seems that the design of the ISSP intervention simply does 
not tackle those issues well and, based on all of the evidence presented above, never will.

\section{DISCUSSION AND CONCLUSIONS}

ISSP is not achieving its anticipated success, and the reasons seem clear. To begin with, there is no convincing 'evidence base'. The review of previous evaluations of intensive programmes shows, overwhelmingly, that they do not work, especially in reducing reconviction rates in the youth justice context.

As Muncie (2004, p. 249) emphasises, the varied 21st century discourses of punishment, diversion and retribution coexist in an uneasy manner. ISSP forms part of this uneasy melange, with aims that tend to conflict: reducing reoffending and the youth custody population, whilst providing effective punishment that satisfies sentencers and the public, and also reducing costs. Solutions are unlikely to be simple. For instance, increasing enforcement rigour will only amplify breach levels, thus increasing non-completion and ultimately increasing reconvictions and imprisonment rates.

In short, ISSP has not: reduced predicted reoffending; ensured adequate surveillance to ensure public protection; ensured rigorous enforcement; had a positive impact upon offenders' attitudes; provided supervision sessions specific to individual needs or offender age; improved young offenders' life chances; ensured adequate incapacitation; brought structure to young offenders' lives; provided strong boundaries and separation from damaging environments or peer groups. Essentially, ISSP in practice is a long way from providing unprecedented levels of surveillance, whilst meeting the expectations of the public that offenders are monitored one-to-one, 24 hours a day and not given the opportunity to reoffend (YJB, 2002, p. 3).
We are therefore left with a dilemma. While ISSP is clearly inadequate to deal with the demands of managing severe and persistent young offenders in the community, there is also much evidence from the youth custody estate that bullying, suicides and problems with restraint are endemic (Carlile Inquiry, 2006; Faze, Benning \& Danesh, 2005; Goldson, 2006). Youth custody reconviction rates also fail to inspire confidence. ISSP is certainly cheaper (though it accounted for f32 million between 2005 and 2007 (YJB, 2007, p. 30), but relatively poor at protecting the public.

Our evidence also suggests that offenders do not see custody as a deterrent. However, young offenders do have clear ideas about what will reduce their offending, and these chime well with much of the 'what works' evidence beyond cognitive behavioural programmes. Neither youth custody, nor ISSP is effective for high risk offenders. Many of our most serious or prolific offenders' comments might superficially seem to err toward custody. However, these offenders are, in effect, asking for their individual needs to be better addressed away from their current milieu, and to be taught job-related skills, possibly in a secure training facility, but in conjunction with supervision, mentoring and other (not necessarily criminal justicebased) support in the community.

Andrews (1995) has argued that 'what works' intervention programmes can contribute to a reduction in reoffending regardless of the setting and it was indeed striking that many of our young offenders acknowledged the benefits of secure care within this study, not only for themselves but for society. Neustatter (2002) has argued that some offenders can even find custody a positive experience and stresses that there should be no taboo in discussing custody as a place for some children. Whelan (2007) has also argued that some offenders can enjoy the 
structure and opportunities that incarceration can provide.

Certainly, some of the most serious offenders in this study suggested that initial custody would be better and more beneficial to them. However, there is an important coda here. Much of what they require from 'custody', eg, job skills training, release to a new area, suitable housing etc, is unlikely to be able to be guaranteed at present and can be provided through means other than custody, if there is a will to do so. The whole regime for dealing with such offenders needs a radical and urgent overhaul, and a review which focuses on the evidence of what does work or is likely to work, rather than on political expediency, is long overdue. One of the most promising avenues to explore may well be Ward and Stewart's (2003) 'good lives' model. However, perhaps 'unpaid work' or 'community service' (CS) is an existing and underrated alternative here. We are currently conducting a further study in Area 1 on CS, and the emerging findings on the same topics explored for ISSP are far more positive.

We also feel it is important to be clear on our perspective regarding the mismatch between the commitment of the ISSP staff, and the tools which ISSP provides in order to achieve its objectives. The words of an ISSP worker excellently sum up the overall qualitative observational findings within our study:

I think the ISSP teams are truly committed people and I admire them for their devotion. I believe that they are working with one hand tied behind their backs and the other one in a big woolly mitten but still try for all they are worth because they really want to make a difference.

As with the enormous volume of intensive supervision research that has gone before,
ISSP, unsurprisingly, has failed to display the promise which the YJB, and New Labour, anticipated. We feel that we have added to the corpus of knowledge on ISSP and have filled some of the gaps in knowledge created by the YJB's own studies. It is clear that, from whatever perspective it is looked at, using any triangulation of methods, ISSP does not work. We have imported failure from North America and used it to fill a rhetorical need and in doing so, have put people at risk. It is time to stop flogging the dead horse!

\section{Notes}

(1) Covering England and Wales only.

(2) The structured actuarial assessment tool that supports youth justice supervision, risk management in England and Wales (see Baker, Jones, Roberts \& Merrington, 2002).

(3) At the time of writing (April 2008) we discovered presentation slides on the YJB website (see http://www.yjb.gov. uk/NR/rdonlyres/E60A4C16-AB644C70-A0E8 E3283B3D740B/0/ISSP Conference2008YJBPresentations.pdf) that claim a lower, though still high, reconviction rate of 74 per cent for ISSP. Furthermore, it is also claimed that 59 per cent of offenders committed less serious offences and 70 per cent offended less frequently. We look forward to the publication of the study on which this was based in due course.

\section{References}

Altschuler, D. (1998). Intermediate sanctions and community treatment for serious and violent juvenile offenders. In R. Loeber \& D. Farrington (Eds.), Serious and Violent Juvenile Offenders: Risk Factors and Successful Interventions (pp. 367-385). Thousand Oaks, CA: Sage Publications. 
Andrews, D. (1995). The Psychology of Criminal Conduct and Effective Treatment. In J. McGuire (Ed.), What Works: Reducing Re-offending: Guidelines from Research and Practice (pp. 35-61). Chichester: Wiley.

Audit Commission. (1996). Misspent Youth: Young People and Crime. London: author.

Baker, K., Jones, S., Roberts, C., \& Merrington, S. (2002). Validity and Reliability of Asset: Findings from the First Two Years of the Use of Asset. Oxford: Probation Studies Unit, Centre for Criminological Research.

Barton, W. H., \& Butts, J. A. (1990). Viable options: Intensive supervision programs for juvenile delinquents. Crime and Delinquency, 36(2), 238-256.

Bottoms, A. E. (1995). Intensive Community Supervision for Young Offenders: Outcomes, Process and Cost. Cambridge: Institute of Criminology.

Brownlee, I. (1995). Intensive Probation with Young Adult Offenders: A Short Reconviction Study. British Journal of Criminology, 35(4), 599-612.

Brownlee, I. D., \& Joanes, D. (1993). Intensive Probation for Young Adult Offenders: Evaluating the Impact of a Non-Custodial Sentence. British Journal of Criminology, 33, 216-230.

Burnett, R., \& Appleton, C. (2004). Joined-up Services to Tackle Youth Crime. British Journal of Criminology, 44(1), 34-54.

Byrne, J. (1990). The future of intensive probation supervision and the new intermediate sanctions. Crime and Delinquency, 36, 6-41.

Canton, R., \& Eadie, T. (2005). Enforcement. In T. Bateman \& J. Pitts (Eds.), The RHP Companion to Youth Justice (pp. 144-150). Lyme Regis: Russell House Publishing.

Carlile Inquiry. (2006). Children in the Secure Estate: An Independent Inquiry Resolution: News from the Restorative Justice Consortium. London: Howard League.

Chapman, T., \& Hough, M. (1998). Evidence Based Practice: A Guide to Effective Practice. London: Home Office.

Clear, T., Flynn, S., \& Shapiro, C. (1987). Intensive supervision in probation: $\mathrm{A}$ comparison of three projects. In B. McCarthy (Ed.), Intermediate Punishments: Intensive Supervision, Home Confinement and Electronic Surveillance (pp. 31-50). Monsey, NY: Criminal Justice Press.

Cook, T., \& Campbell. D. (1979). QuasiExperimentation: Design \& Analysis Issues for Field Settings. Boston: Houghton Mifflin.

Corbett, R. P., \& Petersilia, J. (1994). Up to speed: A review of research for practitioners. Federal Probation, 58(3), 51-56.

Ellis, T. (2000). Enforcement Policy and Practice: Evidence-Based or Rhetoric Based? Criminal Justice Matters, 39, 6-7.

Ellis, T., \& Boden, I. (2005). Is there a unifying professional culture in Youth Offending Teams? A research note. British Society of Criminology 2004 (Vol. 7) Conference Proceedings.

Ellis, T., Hedderman, C., \& Mortimer, E. (1996). Enforcing community sentences: supervisors' perspectives on ensuring compliance and dealing with breach (Home Office Research Study 158). London: Home Office.

Ellis, T., \& Underdown, A. (1998). Strategies for Effective Offender Supervision. London: Home Office.

Ellis, T., \& Winstone, J. (2002). The policy impact of a survey of programme evaluations in England and Wales: towards a new corrections-industrial complex? In J. McGuire (Ed.), Offender Rehabilitation and Treatment: Effective programmes and policies (pp. 333-358). Chichester: John Wiley.

Enos, R., Homan, J. E., \& Carroll, M. E. (1999). Alternative Sentencing: Electronically Monitored Correctional Supervision (2nd ed.). Bristol, IN: Wyndham Hall.

Faze, S., Benning, R., \& Danesh, J. (2005). Suicides in male prisoners in England and Wales 1978-2003. The Lancet, 366, 1301-1302.

Folkard, M. S., Smith, D. E., \& Smith, D. D. (1976). IMPACT: Intensive Matched Probation and After-Care Treatment (Vol. 2) (Home Office Research Study 36). London: HMSO.

Friendship, C., Street, R., Cann, J., \& 
Harper, G. (2004). Introduction: the policy context and assessing the evidence. In G. Harper \& C. Chitty (Eds.), The impact of corrections on re-offending: a review of 'what works' (2nd ed.) (Home Office Research Study 291). London: Home Office.

Fulton, B., Latessa, E. J., Stichman, A., \& Travis, L F. (1997). The State of ISP: Research and Policy Implications. Federal Probation, 61(4), 65-75.

Gendreau, P., Goggin, C., Cullen, F. T., \& Andrews D. A. (2000). The effects of community sanctions and incarceration on recidivism. Forum on Corrections Research, 12(3), 10-13.

Gibb, F., \& Ford, R. (2005, October 28). Row over tagging after fresh youth crime spree. The Times, p. 12.

Goldson, B. (2006). Damage, Harm and Death in Child Prisons in England and Wales: Questions of Abuse and Accountability. Howard Journal, 45(5), 449-467.

Goodstein, L., \& Sontheimer, H. (1997). The implementation of an intensive aftercare program for serious juvenile offenders. Criminal Justice and Behaviour, 24(3), 332-359.

Gray, E., Roberts, C., Merrington, S., Waters, I., Fernandez, R., Hayward, G., et al.. (2005). ISSP: The Final Report. London: Youth Justice Board.

Green, D., Grove, E., \& Martin, N. (2005). Crime and Civil Society, can we become more law abiding people? London: CIVITAS: The Institute for the Study of Civil Society.

Hearnden, I., \& Millie, A. (2004). Does tougher enforcement lead to lower reconviction? Probation Journal, 51(1), 48-58.

Hedderman, C., \& Hough, M. (2004). Getting tough or being effective: what matters? In G. Mair (Ed.), What Matters in Probation (pp. 146-169). Devon: Willan.

HM Inspectorate of Probation. (2005). Inquiry into the supervision of Peter Williams by Nottingham City Youth Offending Team. Retrieved August 13, 2007 from http:// inspectorates.homeoffice.gov.uk/hmi probation/inspect_reports/serious-further- offences/peterwilliamsenquiry.pdf?view = Binary

Home Office. (2002). Justice for All. (Cm 5563). London: HMSO.

Land, K. C., McCall, P. L., \& Williams, J. R. (1990). Something that works in Juvenile Justice: An evaluation of the North Carolina court counsellors' intensive protective supervision randomized experimental project, 1987-1989. Evaluation Review, 14(6), 574-606.

Little, M., Kogan, J., Bullock, R., \& Van der Lann, P. (2004). ISSP: an experiment in multi-systemic responses to persistent young offenders known to children's services. British Journal of Criminology, 44(2), 225-240.

Mair, G.., Lloyd, C., Nee, C., \& Sibbitt, R. (1993). Intensive Probation in England and

Wales: An Evaluation (Home Office Research Study 133). London: HMSO.

Matza, D. (1969). Becoming Deviant. Englewood Cliffs, NJ: Prentice-Hall.

Maynard, G. (2007, July 11). Sex beast raped girl days after being freed. Daily Express.

Moore, R. (2007). Adult offenders' perceptions of their underlying problems: findings from the OASys self-assessment questionnaire (Home Office Findings 284). London: Home Office, Development and Statistics Directorate.

Moore, R., Gray, E., Roberts, C., Merrington, S., Waters, I., Fernandez, R., et al. (2004). ISSP: The Initial Report, Summary. London: Youth Justice Board.

Moore, R., Gray, E., Roberts, C., Taylor, E \& Merrington, S.. (2006). Managing Persistent and Serious Offenders in the Community. Devon: Willan Publishing.

Muncie, J. (2004). Youth and Crime. London: Sage.

Nee, C., \& Ellis, T. (2005). Treating Offending Children: What Works? Legal and Criminological Psychology, 10, 1-16.

Neustatter, A. (2002). Prison can be the right place for kids. Retrieved August 10, 2007, from http://www.newstatesman.com/ 200208190006

Partridge, S., Harris, J., Abram, M., \& Scholes, A. (2005). The Intensive Control and Change 
Programme Pilots: A Study of Implementation in the First Year (Home Office Online Report 48/05). London: Home Office.

Pearson, F. (1987). Final report of research in New Jersey's Intensive Supervision Program. Rutgers University, NJ: Institute for Criminological Research.

Petersilia, J. (1998). A Decade of Experimenting with Intermediate Sanctions: What Have We Learned? Federal Probation, 62(2), 3-9.

Petersilia, J., \& Turner, S. (1990). Intensive Supervision for High-Risk Probationers: Findings from Three Californian Experiments. Santa Monica, CA: RAND.

Petersilia, J., Turner, S., \& Deschenes, E. (1992). Intensive Supervision Programs for Drug Offenders. In J. M. Byrne, A. J. Lurigio \& J. Petersilia (Eds.), Smart Sentencing: The Emergence of Intermediate Sanction. Newbury Park, CA: Sage.

Roberts, C. H. (1989). Hereford \& Worcester Young Offender Project First Evaluation Report. University of Oxford, Department of Social and Administrative Studies.

Robson, C. (2002). Real World Research: A resource for social scientists and practitionerresearchers (2nd ed.). Oxford: Blackwell.

Sherman, L. W., Gottfredson, D., MacKenzie, D., Eck, J., Reuter, P., \& Bushway, S. (1997). Preventing Crime: What works, what doesn't, what's promising: $A$ report to the United States Congress. Washington DC: National Institute of Justice.

Shute, S. (2007). Research Summary 4: Satellite Tracking of Offenders: A Study of the Pilots in England and Wales. London: Department of Justice.

Slack, J. (2007). 1,000 danger convicts are set free without tags. Retrieved July $13^{\text {th }}$, 2009, from http://www.dailymail.co.uk/news/article469851/1-000-danger-convicts-set-freetags.html

Smith, R. (2003). Youth Justice: Ideas, Policy, Practice. Devon: Willan.

Smith, R. (2007). Youth Justice: Ideas, Policy, Practice (2nd ed.). Devon: Willan.

Solomon, E., \& Garside, R. (2008). Ten years of Labour's youth justice reforms: an independent audit. King's College London: Centre for Crime and Justice Studies.

Stephenson, M., Giller, H., \& Brown, S. (2007). Effective Practice in Youth Justice. Devon: Willan.

Stone, S. B., \& Fulton, B. A. (1995).

Achieving public safety through rehabilitation and reintegration: The promise of a new ISP. In J. O. Smykla \& W. L. Selke (Eds.), Intermediate Sanctions: Sentencing in the 1990s (pp. 115-134). Cincinnati, $\mathrm{OH}$ : Anderson Publishing.

Sutherland, A., Taylor, E., Gray, E., Merrington, S., \& Roberts, C. (2007). Piloting 12-month ISSP, Evaluation and Research Findings. London: Youth Justice Board.

Turner, S., \& Petersilia, J. (1992). Focusing on high-risk parolees: An experiment to reduce commitments to the Texas Department of Corrections. Journal of Research in Crime and Delinquency, 29(1), 34-61.

Ward, T., \& Stewart, C. (2003). Criminogenic needs and human needs: A theoretical model. Psychology, Crime and Law, 9(2), 125-143.

Weibush, R. G. (1993). Juvenile intensive supervision: The impact on felony offenders diverted from institutional placement. Crime and Delinquency, 39(1), 68-89.

Weibush, R. G.., Wagner, D., McNulty, B., Wang, Y., \& Le, T. N. (2005). Implementation and outcome evaluation of the Intensive Aftercare Program: Final report. Washington, DC: US Department of Justice, Office of Juvenile Justice and Delinquency Prevention.

Whelan, R. (2007). Opinion: Prison can be the answer. Retrieved August 10, 2007, from http://www.communitycare.co.uk/Articles/ 2007/05/03/104347/opinion-prison-canbe-the-answer.html

Whiting, E., \& Cuppleditch, L. (2006). Reoffending of Juveniles: Results from the 2004 Cohort. London: Home Office.

Youth Justice Board. (2002). Intensive Supervision and Surveillance Programme (ISSP): An Option for Dealing with Prolific and Serious Young Offenders (leaflet). London: Youth Justice Board. 
Youth Justice Board. (2003). Corporate and Business Plan 2003/04 to 2005/06. London: author.

Youth Justice Board. (2004, September 14). Robust community programme for young offenders to go nationwide, ISSP: marked reduction in both frequency and seriousness of offending (press release). London: author.

Youth Justice Board. (2007). Annual Report and Accounts 2006/07. London: author. 